\title{
Naar een zekere toekomst?
}

Citation for published version (APA):

Hasman, A. (1986). Naar een zekere toekomst? Maastricht University. https://doi.org/10.26481/spe.19860418ah

Document status and date:

Published: 18/04/1986

DOI:

10.26481/spe.19860418ah

Document Version:

Publisher's PDF, also known as Version of record

\section{Please check the document version of this publication:}

- A submitted manuscript is the version of the article upon submission and before peer-review. There can be important differences between the submitted version and the official published version of record.

People interested in the research are advised to contact the author for the final version of the publication, or visit the DOI to the publisher's website.

- The final author version and the galley proof are versions of the publication after peer review.

- The final published version features the final layout of the paper including the volume, issue and page numbers.

Link to publication

\footnotetext{
General rights rights.

- You may freely distribute the URL identifying the publication in the public portal. please follow below link for the End User Agreement:

www.umlib.nl/taverne-license

Take down policy

If you believe that this document breaches copyright please contact us at:

repository@maastrichtuniversity.nl

providing details and we will investigate your claim.
}

Copyright and moral rights for the publications made accessible in the public portal are retained by the authors and/or other copyright owners and it is a condition of accessing publications that users recognise and abide by the legal requirements associated with these

- Users may download and print one copy of any publication from the public portal for the purpose of private study or research.

- You may not further distribute the material or use it for any profit-making activity or commercial gain

If the publication is distributed under the terms of Article $25 \mathrm{fa}$ of the Dutch Copyright Act, indicated by the "Taverne" license above, 


\author{
REDE \\ Uitgesproken bij de aanvaarding \\ van het ambt van hoogleraar in de \\ MEDISCHE INFORMATICA \\ aan de Rijksuniversiteit Limburg \\ op vrijdag 18 april 1986 \\ door \\ dr. ir. A. HASMAN.
}


Computers zijn reeds lang geen bijzonderheid meer binnen de gezondheidszorg. In het ziekenhuis wordt met behulp van het ziekenhuisinformatiesysteem een groot deel van de administratie uitgevoerd, terwijl decentraal in de afdelingen $\mathrm{zg}$. dedicated systemen kunnen zijn opgesteld, veelal ter ondersteuning van het medisch handelen.

In mei organiseren Nederlandse en Belgische verpleegkundigen hun eerste informatica congres om over de mogelijkheden van computersystemen op hun terrein te discussiëren.

Sinds kort zijn er huisarts informatiesystemen op de markt, waarmee in eerste instantie de praktijkvoering van de huisarts kan worden verbeterd. Apotheken beschikken over systemen, waarmee naast de afhandeling van zaken yan financieel-economische aard ook een zekere vorm van medicatiebewaking kan worden uitgevoerd. Aan de kruisverenigingen is de automatisering eveneens niet voorbijgegaan. Naast een landelijke ontwikkeling is men plaatselijk bezig met een systematische beschrijving van het verpleegkundig handelen. Ziekenfondsen en ziektekostenverzekeraars beschikken over eigen informatiesystemen. Vorig, jaar publiceerde de staatssecretaris van WVC de nota 'Uitvoeringsorganisatie wettelijke gegevensstromen in de gezondheidszorg', waarin de realisatie van een algemene uitvoeringsorganisatie, via welke de wettelijke gegevensstromen zullen worden geleid, wordt besproken.

Kortom, deze niet uitputtende opsomming wettigt de conclusie, dat de computer niet meer weg te denken is uit de gezondheidszorg.

Ook in het onderwijs neemt de computer een steeds voornamer plaats in. Hierbij denken we niet alleen aan de ondersteuning van het medisch informatica onderwijs. Ook andere vakgebieden kunnen van de verworvenheden van het computer ondersteund onderwijs profiteren door bijvoorbeeld gebruik te maken van auteurssystemen om het lesmateriaal te ontwerpen.

Computersystemen zijn veelal onmisbaar bij het doen van onderzoek. Klinisch onderzoek, ondersteund door een database management systeem, vindt meer en meer plaats. Het gebruik van computersystemen ten behoeve van onderzoek op het terrein van signaalanalyse en patroonherkenning is ingeburgerd. De toepassing van expertsystemen ter ondersteuning van de medische beslutvorming begint op gang te komen.

Niet alleen binnen de gezondheidszorg zien we de opkomst van computersystemen. Veel produktieprocessen, allerlei dienstverlening en zelfs het politick bedrijf veranderen door de opmars van de computer.

Optimisten houden ons voor, dat informatiesystemen grote veranderingen ten goede zullen brengen: de mens zal vrijgemaakt worden van arbeid, zijn vervreemding zal worden opgeheven en plaatsmaken voor echte menselijkheid en culturele groei. Computers stellen ons in staat de toekomst onder controle te krijgen en te houden. Het beheersen van de toekomst, via welke de verlossing van de mens van allerlei problemen moet worden bewerkstelligd, zal echter tot gevolg hebben, dat de mens steeds meer in zijn vrijheid wordt beperkt. 
Hij moet zich gaan gedragen als cen raderije in het totale system om er voor te zorgen, dat de toekomst inderdaad gedeterminerd kan worden. In concrete gevallen blikt namelikk, dat noch het gedrag van mensen afzonderlik, noch dat van mensenmassa's op betrouwbare wijze voorspeld kan worden. De mens wordt dus slaaf van zijn eigen maaksel. Am Ende hängen wir doch ab von Kreaturen, die wir machten (Goethe).

De rol, die de computer kan spelen bij het ontwerpen van de toekomst "is nog primair ondersteunend. De mens, in ieder geval een kleine elite, formuleer mogelijke modellen en laat de keuze van het beste model aan de kiezer over. Dat dit nauwelijks op democratische wijze kan plaatsvinden - ondanks de veel verkondigde stelling van het tegendeel, namelijk dat in een informatiemaatschappij de democratie veel beter tot haar recht kan komen - zal hopelijk duidelik zijn. Een onafhankelijker rol wordt de computer toegedicht, wanneer het gaat om kunstmatige intelligentie. Kenners beweren, dat computers tot intelligent gedrag in staat zullen zijn. Afgezien van het feit, dat men intelligent gedrag dan eerst goed moet definiëren, zal het toch duidelijk zijn, dat er hoogstens sprake is van afgeleid intelligent gedrag, namelijk dat gedrag, dat de mens er van te voren via zijn programma's heeft ingestopt. Dat de maker het gedrag wan een dergelijk programma soms niet meer kan woorspellen, doet hier aan niets af. De overdreven verwachtingen van sommige wetenschapsmensen ten aanzien van de mogelijkheden van kunstmatige intelligentie zijn in ieder geval tot nog toe niet uitgekomen.

I $k$ heb hier ten aanzien van de rol van computersystemen in de maatschappij twee mogelijkheden toegelicht, waarvan ik hoop te hebben aangetoond, dat ze tot verkeerde toepassingen en verwachtingen kunnen leiden. Daarbij heb ik het probleem van de privacy nog niet eens aan de orde gesteld.

Mijn positie ten aanzien van de waardering van mogelijke computertoepassingen in de maatschappij wil ik daarom aan het begin van mijn betoog reeds duidelijk onder woorden brengen. $\mathrm{k}$ ga uit van de stelling, dat de computer alleen gebruik $\mathrm{t}$ zal moeten worden om de mens te ondersteunen, niet om de mens te beheersen. De mens moet de gevolgen van zijn beslissingen kunnen overzien en daarvoor verantwoordelijkheid kunnen dragen. Hij mag geen slaaf van het systeem worden.

Ik zal nu proberen wat krenten uit de medische informatica pap te halen en deze $\mathrm{U}$ de komende veertig minuten voorschotelen. Daarbij zal ik geen volledigheid nastreven. Het zal blijken welke terreinen bijvoorbeeld door dit vakgebied worden bestreken en op welke wijze de problemen worden aangepakt. 
Alvorens een aantal woorbeelden de revue te laten passeren, dienen we ons eerst af te vragen wat het vakgebied medische informatica nu eigenlijk inhoudt.

Volgens de definitie van het Nederlands Normalisatie Instituut is informatica het vakgebied, dat zowel het verschijnsel informatie bestudeert in relatie tot informatiesystemen als hei verwerken, overdragen en gebruiken van informatie; in hoofdzaak, maar niet noodzakelijkerwijze, met computers en teleconmunicatiesystemen.

Voor medische informatica geldt mutatis mutandis dezelfde definitie, met dien verstande, dat daarbij nadrukkelijk gesteld moet worden, dat de gegevensverwerking begint en eindigt bij de patiënt en derhalve noodzaakt tot de bestudering van biotische, chemische, fysische, organisatorische, diagnostische en therapeutische processen.

Zoals $U$ misschien opmerkte sprak ik van gegevensverwerking terwijl in de definitie van het NNI over informatieverwerking wordt gesproken. Hoewel het onderscheid tussen gegevens en informatie niet door iedereen gemaakt wordt, is er naar mijn mening pas sprake van informatie als de mens gegevens interpreteert en er een betekenis aan hecht. Computers verwerken gegevens, namelijk geformaliseerde voorstellingen van feiten en ideeën. Binnen het vakgebied medische informatica worden een drietal processen bestudeerd:

* de processen, die de organisatie van de gezondheidszorg betreffen,

* de processen, die zich afspelen in de patiënt en

* de processen, die zich afspelen in het brein van de arts.

Op de eerste soort van processen zal ik hier niet uitgebreid ingaan. Het betreft processen, die betrekking hebben op beleid en beheer of processen die de communicatie tussen verschillende sectoren van de gezondheidszorg bevorderen.

\section{PROGRAMMEREN}

Informatici maken gebruik van computersystemen. Teneinde deze computersystemen datgene te laten uitwoeren wat men zich als doel heeft gesteld, dient deze apparatuur geprogrammeerd te worden.

Daartoe wordt een programma geschreven, waarmee stap voor stap via opdrach ten wordt aangegeven, wat de computer moet doen. Deze opdrachten worden geïnterpreteerd door de zogenaamde centrale verwerkingseenheid en uitgevoerd met behulp van elektronische componenten, die zich in Iwee toestanden kumnen bevinden. Dat is dan ook de reden, dat de opdrachten aan de centrale verwer. kingseenheid worden weergegeven met behulp van het tweetallig stelsel.

Zoals $\mathrm{U}$ zich kunt voorstellen is deze manier van programmeren niet erg gebruikersvriendelijk. Al snel werden er daarom zogenaamde tweede en derde genera- 
tietalen ontwikkeld. Vooral de opdrachten in derde generatietalen lijken veel op een deelverzameling wan de engelse taal. De productiviteit van programmeurs nam door deze ontwikkelingen enorm toe. Momenteel beschikken we zelfs over vierde generatietalen, waarmee problemen van een bepaald type nog sneller kunnen worden opgelost.

Het ontwerpen van informatiesystemen is echter niet alleen een zaak van programmeren. In feite vormt het programmeren de afsluiting van de fasen van systeemanalyse en systeemontwerp. Wil men bepaalde funkties automatiseren dan zullen deze funkties tot in detail geanalyseerd moeten worden, waarbij men geen mogelijkheid over het hoofd mag zien. Dat dit niet eenvoudig is moge uit het wolgende blijken.

Stelt $U$ zich voor, dat we een automatisch bestuurde auto hebben ontworpen. Om de auto door het verkeer te loodsen, dienen we in ieder geval te beschikken over een programma dat voorschrijft, hoe te handelen bij het naderen van een verkeerslicht. Eenvoudig, zult U zeggen. Het programma moet luiden: bij rood licht stoppen, bij groen licht doorrijden en bij oranje licht stoppen, tenzij de afstand tot het verkeerslicht en de snelheid van de auto dit niet toelaten. Dit laatste criterium kan in de vorm van een formule in het programma worden ingebracht. Als we dit programma in de praktijk uittesten, zal inderdaad blijken, dat het nog zo gek niet is. Totdat er een ambulance nadert met loeiende sirene en lichtsignalen. De bedoeling van de chauffeur van de ambulance is voor óns duidelijk: hij wil door rood licht rijden. Ons programma heeft echter geen rekening gehouden met deze uitzonderingssituatie waardoor de auto zal doorrijden met misschien wel catastrofale gevolgen. Dit eenvoudige voorbeeld maakt al duidelijk, dat een systeemanalist bedacht moet zijn op alle eventualiteiten en uitzonderingssituaties. Daartoe zal de systeemanalist zich moeten inwerken op het terrein, dat wordt geautomatiseerd. Steeds zal blijken, dat systemen niet ontwikkeld kunnen worden zonder een aktieve participatie van de potentiële gebruikers. Deze gebruikers kunnen echter alleen nuttige gesprekspartners van onze systeemanalist zijn, als ze naast kennis van het eigen vakgebied beschikken over een flinke dosis informatica kennis. Dat men elkaar vaak niet goed begrijpt wordt wel bewezen door het feit, dat zoveel automatiseringsprojekten toch niet dat succes blijken te zijn, dat men er van te voren van verwachtte.

Niet voor niets wijzen de initiatiefnemers voor de oprichting van wat toen nog de informatica universiteit werd genoemd op de noodzaak tot de opleiding van 'boundary spanners": deskundigen op bepaalde terreinen, die zich een diepgaande kennis van de informatica hebben eigen gemaakt. Deze boundary spanners kunnen een brug slaan tussen informatici en gebruikers, zodat in ieder geval wordt voorkomen, dat men elkaars taal niet verstaat.

Ook in de gezondheidszorg bestaat uiteraard behoefte aan dit type mensen. Studenten, die zich verder willen bekwamen in de medische informatica door het volgen van keuzeblokken en het verrichten van onderzoek op dit gebied, dienen hiertoe in de gelegenheid te worden gesteld. 


\section{DATABANKEN}

Wanneer een arts onderzoek wil verrichten naar het wóórkomen van symptomen bij bepaalde ziekten of een indruk wil krijgen van het resultaat van een bepaalde therapie na een aantal jaren van follow-up, moet hij eerst vaststellen welke gegevens hij voor het beoogde onderzoek nodig heeft. Een dergelijke analyse lijkt gemakkelijk - de vraagstelling is immers bekend - in de praktijk blijkt herhaaldelijk, dat bepaalde voor de beantwoording van de vraagstelling belangrijke gegevens, vergeten zijn.

Teneinde de gegevens van veel patiënten te kunnen vastleggen voor latere verwerking ontwerpt de arts een invulformulier, waarop de vragen zijn vermeld, eventueel aangevuld met een lijst van mogelijke antwoorden, veelal in gecodeerde vorm, om de latere verwerking te vergemakkelijken. Dit invulformulier wordt dan ter hand gesteld van een aantal collegae, die de onderzoeker helpen bij het verzamelen wan gegevens van zoveel mogelijk patiënten. Zijn de formulieren ingevuld en verzameld, dan begint het 'turven'. De resultaten worden veelal weergegeven in de vorm van tellingen, histogrammen of kruistabellen. Zelfs als de onderzoeker slechts beschikt over de gegevens van een klein aantal patiënten zal hij bemerken, dat het verkrijgen van de eerder genoemde overzichten met behulp van de gegevens uit de invulformulieren een tijdrovend karwei is met een grote kans op het maken van fouten. In zo'n geval zal de onderzoeker uitzien naar mogelijkheden dit proces te versnellen en de nauwkeurigheid ervan te verhogen. Computersystemen komen nu in het visier. Menige arts is echter nog steeds de mening toegedaan, dat het veel tijd zal kosten, voordat zijn onderzoek met behulp van een computer ondersteund kan worden. Alles moet immers geprogrammeerd worden, aangezien zijn onderzoek zich onderscheidt van ander onderzoek, dat wellicht al wel met behulp van een computersysteem wordt uitgevoerd. Wanneer de onderzoek er echter een bezoek aflegt bij de capaciteitsgroep Medische In formatica en Statistiek, zal hij niet alleen bemerken, dat men reeds eerder met dit soort problemen te maken heeft gehad - de onderzoeker zou ook niet anders verwachten maar dat zijn onderzoek met weinig moeite met behulp van de computer kan worden uitgevoerd. Van programmeren in de eigenlijke zin des woords blijkt geen sprake te zijn: de derde generatie computertalen zijn inmiddels ook hier vervangen door de vierde generatietalen, behorend bij database management systemen.

Het gebruik van deze database management systemen vergemakkelijkt de uitwoering van klinisch onderzoek enorm. Niets staat onze onderzoeker meer in de weg om een goed onderzoek te doen, tenminste zo lijkt het. Toch kan de onderzoeker - ondanks de beschikbaarheid van een database management systeem en een statistisch pakket - resultaten verkrijgen, die de toets der wetenschappelijke kritiek niet kunnen doorstaan. Hoe dat komt, zullen we nu onderzoeken.

Met behulp van computers wordt het mogelijk gegevens van grote aantallen patiënten op te slaan en te verwerken. Bij het gebruikelijke handwerk was het aantal patiënten noodzakelijkerwijs gering. De onderzoeker kende zijn gegevens en had een indruk van de betrouwbaarheid ervan. Dit is veelal niet het geval bij het gebruik van computersystemen. De gegevens worden lang niet altijd door de onder- 
zoeker zelf ingevoerd, terwijl hij vaak ook niet de leverancier ervan is. Hij kan derhalve de betrouwbaarheid wan de gegevens minder goed beoordelen. Ondanks het feit, dat grotere aantallen patiënten bij een onderzoek kunnen worden betrokken, waardoor kleinere verschillen tussen hypotheses vastgesteld kunnen worden, kan het voordeel yan een groter aantal patiënten te niet gedaan worden door een slechte kwaliteit van de gegevens. Het simpele feit, dat gegevens met behulp van een computer worden werwerkt houdt niet in, dat daardoor de kwaliteit wan de ermee verkregen resultaten zal werbeteren. In tegendeel! Uitgebreide controles op de ingevoerde gegevens zijn daarom noodzakelijk.

Onze onderzoeker begon goed: hij had een vraagstelling op basis waarvan hij naging welke gegevens nodig waren ter beantwoording ervan. Het komt echter nog al eens voor, dat een arts nog niet weet, wat hij precies wil onderzoeken. Alleen de grotelijnen staan hem duidelijk voor de geest. Om dit euvel te ondervangen, produceert hij een vragenlijst van vele kantjes en wil hij werken met grote aantallen patiënten. Door middel van exploratief onderzoek op dit bestand zullen in een latere fase de vragen vanzelf wel komen, zo redeneert hij dan. En inderdaad, die vragen komen ook. Als de onderzoeker het uithoudingsvermogen heeft en collegae bereid vindt eveneens door te gaan, resulteert in veel gevallen na verloop van tijd een aardig 'datakerkhof'. Niet dat de gegevens niet bruikbaar zouden zijn voor het bedenken van vraagstellingen: zoals dat met een kerkhof het geval is, roepen ook de gegevens meer vragen op, dan er beantwoord kunnen worden. In de eerste plaats blijkt dan, dat er additionele gegevens nodig zijn ter beantwoording van de opgeworpen vragen. Deze antwoorden kunnen alleen verkregen worden door weer terug te gaan naar de patiënt, met alle problemen van dien. In de tweede plaats is het mogelijk, dat de gegeven antwoorden anders uitgevallen waren, als men van te voren had geweten voor welk doel de gegevens werden verzamelld.

Is de vraagstelling van te voren wel bekend dan zullen de hieruit voortvloeiende vragen voor alle deelnemende partijen eenduidig moeten zijn. Dit geldt uiteraard ook voor voorgestelde coderingen. Ook dient men de vragen zo veel mogelijk zo te stellen, dat de onderzoeker niet eerst zelf moet rekenen of interpreteren. Uit onderzoek is gebleken dat, wanneer de onderzoeker de gegevens zelf moet transformeren, de kans op het maken van fouten enorm toeneemt.

\section{COMPLEX REKENWERK}

Voor een insider op het gebied van de medische informatica zal het duidelijk zijn, dat ik in het voorgaande de eerste twee niveaus van informatieverwerking, zoals deze door van Bemmel zijn gedefinieerd, besproken heb. Bepalend voor het onderscheid tussen de niveaus is de relatieve invloed van computer en mens. Bij de hierboven behandelde niveaus van communicatie en bestanden is de invloed van de computer groot en de creatieve inbreng van de mens gering. Wanneer we ons in het volgende gaan bezighouden met de hogere niveaus zal blijken, dat de inyloed van de computer zal afnemen en die van de mens toenemen.

Het derde niveau is dat van automatisering en rekenen. Daarvan volgen nu een aantal voorbeelden. 


\section{RÖNTGENDIAGNOSTIEK}

In de röntgendiagnostiek spelen computers een steeds belangrijker rol. Met behulp van de computer is het mogelijk geworden opnames van dwarsdoorsneden van de patiënt te verkrijgen in plaats van de gebruikelijke schaduwbeelden. Het principe van de zogenaamde computertomografie wil ik als volgt duidelijk maken. U hebt net een nieuwe auto gekocht en rijdt daarmee opgetogen naar een goede vriend om de wagen te showen. De vriend zal om de auto heen lopen en deze van alle kanten bekijken. Door samenvoegen van deze indrukken verkrijgt de vriend een totaalimpressie van de auto. Op dezelfde wijze wordt via $C T$ een beeld verkregen van het inwendige van de mens. Door onder éen hoek een röntgenfoto te maken kan men niet vaststellen, hoe de verdeling van de onderscheiden weefsels in een dwarsdoorsnede is. Door nu opnames onder verschillende hoeken te maken is het via berekening mogelijk de precieze plaats van de organen binnen de dwarsdoorsnede te bepalen. Tomografie houdt dus in, dat het objekt, in ons geval de patient, als het ware in plakjes wordt gesneden en dat daarvan foto's worden gemaakt.

Een andere afbeeldingstechniek maakt gebruik van kernspinresonantie. In dit geval wordt gewerkt met magnetische velden en radiogolven. Hoewel het fysisch principe van de beeldvorming verschillend is, kan een dwarsdoorsnede met dezelfde programmatuur berekend worden, die ook bij CT wordt toegepast.

Hoewel er nog veel meer valt uit te wijden over computertoepassingen in de röntgendiagnostiek, bijvoorbeeld over digitale subtractietechnieken, picture archiving, de trend om te komen tot volledige digitale röntgendiagnostiek, waarbij de röntgenfoto gaat verdwijnen, moet ik het in verband met de tijd helaas hierbij laten.

\section{NUCLEAIRE GENEESKUNDE}

Gaat het bij de röntgendiagnostiek om veelal anatomische informatie, in de nucleaire geneeskunde staat naast anatomie de funktie centraal.

Om organen zichtbaar te maken wordt een met een radioaktief isotoop gelabelde stof ingespoten. Deze stof is zo gekozen, dat hij voornamelijk wordt opgeslagen in hel orgaan van interesse. De door dit orgaan uitgezonden straling wordt gedetekteerd met behulp van een zogenaamde gammacamera. Voor het genereren van beelden wordt gebruik gemaakt van computersystemen.

Bij hartstudies worden er van het hart een groot aantal opnames gemaakt in opeenvolgende fasen wan de contractie. Aangezien het hart zo'n tachtig keer per minun samentrekt, duurt een contractie met de daarop volgende relaxatie van de hartspier minder dan een seconde. Wil men in deze tijd bijvoorbeeld een veertigtal opnames maken, dan zal de belichtingstijd per beeld niet meer dan een vijfentwintig milliseconden bedragen. De opname is in zo'n geval zwaar 'onderbelicht".

Als het nu mogelijk is dezelfde foto telkens te belichten, wanneer het hart zich in een bepaalde contractiefase bevindt, kan wel een goed beeld worden verkicgen. Het electrocardiogram biedt de mogelijkheid het begin van de contractiefase 
yan het hart te bepalen. Door middel van elektrodes kan men aan de buitenkant van de patiént zich een indruk vormen van de elektrische werking van de hartspier. In het ECG verschijnt het QRS-complex, waarvan de R-top woor ons doel geschikt is. Deze R-top kunnen we namelijk gebruiken om bij wijze van spreken de sluiter van het fototoestel te bedienen. De R-top geeft aan, dat het hart elektrisch wordt gestimuleerd, zodat de kontraktie volgt. De R-top kan dus opgevat worden als het startschot. Na de detektie van een R-top maken we de eerste opname met een belichtingstijd van vijfentwintig milliseconden, direkt daarna starten we de tweede opname van vijfentwintig milliseconden enz.

Als alle opnames zijn gemaakt, wachten we tot de volgende R-top in het ECG verschijnt en start het proces opnieuw. Op deze wijze kunnen we de belichtingsduur per opname kunstmatig vergroten, waardoor beelden van een goede kwaliteit kunnen worden verkregen. De beelden kunnen met behulp van beeldbewerkingsmethoden worden verbeterd, terwijl de beweging van de hartkamer kan worden gekwantiseerd, nadat eerst de omtrek ervan is bepaald.

\section{RADIOTHERAPIE}

Begeven we ons nu op het terrein van de therapie. Radiotherapie is die vorm van therapie, waarbij men met behulp van gerichte bundels een tumor tracht te vernietigen, zonder dat daarbij het normale weefsel, dat ook stralengevoelig is, te veel wordt belast. Vroeger werd de bestralingsplanning door laborantes uitgevoerd.

Hierbij werd gebruik gemaakt van transparanten, waarop de dosisverdeling, veroorzaakt door de stralenbundels, door middel van isodosislijnen - dus lijnen van gelijke dosis - is aangebracht.

Deze transparanten werden gelegd over een getekende dwarsdoorsnede van de patient, die bepaald was ter hoogte van de tumor. Op deze doorsnede was de plaats en omvang van de tumor en indien nodig de plaats van stralengevoelige organen, zoals bijvoorbeeld het ruggemerg, ingetekend. Door een aantal bundels onder verschillende hoeken op de tumor te richten, bereikt men dat de tumor ten gevolge van iedere bundel een dosis straling te verwerken krijgt, terwijl het normale weefsel maar door een enkele bundel wordt getroffen. De dosisverdeling ten gevolge van deze combinatie van bundels werd bepaald door het optellen van de doses behorend bij de elkaar snijdende isodosislijnen van de verschillende bundels. Dit werk nam vaak een aanmerkelijke tijd in beslag. Als dan uiteindelijk bleek, dat de dosisverdeling niet geheel voldeed, werd de berekening meestal niet overgedaan, maar wijzigde de radiotherapeut op basis van zijn ervaring de bestralingsconfiguratie.

Het proces van dosisberekening leent zich uitstekend voor computerondersteuning. In Nederland was het onder andere van de Geyn, die op dit gebied veel oorspronkelijk werk heeft verricht. Hij introduceerde een benadering, waarbij de dosisverdeling voornamelijk analytisch kon worden beschreven, zodat het aantal noodzakelijke bundelmetingen tot een minimum beperkt kon blijven. Bij een andere benadering wordt de werkwijze van de laborantes gesimuleerd, waarbij de 
dosisverdeling veroorzaakt door een bundel in de vorm van een matrix van getal. len in de computer wordt opgeslagen.

Door de komst van de computertomografie is het mogelijk geworden te corrigeren woor verschillen in absorptie ten gevolge van verschillen in elektronendichtheid van het weefsel, waardoor een nauwkeuriger dosisverdeling verkregen kan worden. Dit is belangrijk, omdat afwijkingen van de optimale dosis in de orde van $\pm 5 \%$ het resultaat van de therapie in negatieve zin kunnen beinvloeden. Door de introductie van planning met behulp van de computer, van geautomatiseerde verificatie van de instellingen van bestralingsvoorschriften en door de registratie van therapeutische verrichtingen kon de kwaliteit van de behandeling van patiënten verbeterd worden.

\section{MEDISCHE BESLUITVORMING}

We zijn inmiddels aanbeland bij het volgende niveau van informatieverwerking, waarbij de invloed van de mens nog groter is. Dit is het niveau van herkennen en beslissen.

Artsen verzamelen via anamnese, lichamelijk onderzoek, laboratoriumonderzoek en ander technisch onderzoek zoals röntgendiagnostiek of elektrocardiografie gegevens over patiënten, waarmee ze trachten tot een diagnose te komen op basis waarvan het beleid kan worden vastgesteld.

De arts beschikt over de mogelijkheid via laboratoriumbepalingen steeds meer over zijn patiënten aan de weet te komen. Toch wordt hij keer op keer geconfronteerd met diagnose en therapie situaties, waarbij zijn gegevens niet compleet zijn. In zulke gevallen beslist de arts onder onzekere omstandigheden over diagnose of therapie.

Het is bekend, dat artsen fouten maken bij het stellen van een diagnose. Ondersteuning met behulp van computers zou hierin verbetering kunnen brengen. Ruwweg zijn er twee verschillende aanpakken om tot een diagnose te komen. Een deterministische aanpak, waarbij de symptomen verklaard worden met behulp van een model, dlat gebaseerd is op kennis van de anatomie, fysiologie, biochemie en pathologie. Daarnaast is er een aanpak, gebaseerd op de ervaring, dat er een correlatie bestaat tussen waarnemingen en ziekten. Een deterministisch model kan daarbij als aanvulling dienen om inzicht te verkrijgen in de vraag, welke waarnemingen bij een bepaalde ziekte van belang kunnen zijn.

\section{LOGISCHE KLASSIFIKATIEMETHODEN}

Logische klassifikatiemethoden maken gebruik van een reeks beslissingen van de vorm: als $\mathrm{A}$ waar is, dan volgt daaruit $\mathrm{B}$. Een bekende implementatie is de beslissingsboom. Elke beslissing verkleint het aantal mogelijkheden (bijvoorbeeld diagnoses) totdat er uiteindelijk één overblijft.

Een vorm van zo'n beslissingsboom is het klinisch algoritme. Met behulp van een dergelijk algoritme is het bijvoorbeeld mogelijk paramedisch personeel taken te laten overnemen, die anders door de arts zelf moeten worden uitgevoerd. Artsen 
kumnen overigens ook van dergelijke algoritmen gebruik maken, bijvoorbeeld bij de behandeling van hypertensie patiënten.

\section{STATISTISCHE TECHNIEKEN}

Een bezwaar van logische klassifikatietechnieken is, dat er alleen uitspraken gedaan kunnen worden, die "waar' of 'niet waar' zijn. Vaak is echter niet met zekerheid te zeggen of iets al dan niet waar is. Symptomen kunnen bij een ziekte voorkomen, maar een afzonderlijke patiënt behoeft dit symptoom niet te hebben, hoewel hij toch aan de ziekte lijdt.

Uitspraken in de geneeskunde zijn soms niet voldoende scherp afgebakend en daarom moeilijk met waar of niet waar te beantwoorden. In het leven van alledag hebben we met dezelfde problematiek te maken. De vraag bijvoorbeeld of iemand oud is, zal voor niemand moeilijk te beantwoorden zijn, als het gaat om een persoon van tachtig jaar. Maar hoe luidt het antwoord bij een persoon van zestig? Om deze problemen aan te kunnen is er een alternatieve logica bedacht, de leer van de vage verzamelingen ('fuzzy logic'), waarbij men onder andere aan kan geven in welke mate een objekt tot een bepaalde klasse behoort. Op deze logica zal ik hier niet verder ingaan maar direkt overstappen naar de bespreking van statistische klassifikatietechnieken.

Een veel gebruikte technick in deze groep is de regel van Bayes. Met behulp wan deze regel kan men de kans op het hebben van een van te voren vastgestelde verzameling van ziekten bepalen. Een student in de geneeskunde studeert uit leerboeken, waarin per ziekte een opsomming van de kenmerken ervan wordt gegeven: hoe vaak komen bepaalde symptomen voor, wat is het beloop van de ziekte, etc. Geconfronteerd thet de werkelijkheid zal de student tot zijn ellende ontdekken, dat patiënten de naam van de ziekte niet op hun voorhoofd dragen en dat hij dus verplicht is de opgedane kennis uit de leerboeken omgekeerd toe te passen. En dan blijkt, dat symptomen meestal bij meerdere ziekten voorkomen. Bayes heeft zich de ellende van deze studenten - en niet alleen van hen, maar ook van meer ervaren medici - aangetrokken, misschien wel uit een soort beroepsdeformatie: Bayes was namelijk predikant.

Hij formuleerde cen statistische regel, waarmee - onder een aantal voorwaarden - de kans op de versehillende in aanmerking komende ziekten kan worden berekend, als wordt aangegeven welke symptomen bij de patiënt voorkomen en welke niet. Echter . . voor niets gaat de zon op. Om de regel te kunnen toepassen, dient men eerst te beschikken over een hele serie van kansen. De kans op het vóorkomen van de ziekten in de populatie en de kansen, dat de verschillende symptomen bij deze ziekten worden waargenomen. Om de kansen nauwkeurig te kunnen bepalen dient men over de gegevens van een groot aantal patiënten te beschikken, zelfs als men van de veelal foute veronderstelling uitgaat, dat de symptomen bij een ziekte onathankelijk van elkaar zijn. Zijn er onvoldoende palienten dan kan men nog altijd een beroep doen op specialisten om de kansen in te schatten. Deze aanpak blijkt in de praktijk echter slechtere resultaten op te leveren. 
De regel van Bayes wordt in de geneeskunde veelvuldig toegepast - meestal echter in een researchomgeving. Ten behoeve van de analyse van vectorcardiogrammen - een soort ECG's - wordt de regel toegepast in het programma van Pipberger, terwijl de Dombal en collegae deze methode toepasten om de diagnose van patienten met acute buikklachten vast te stellen. Dit laatste programma bleek betere resultaten op te leveren dan waartoe zelfs ervaren specialisten in staat waren. In de periode, dat het systeem schaduw draaide, gingen de specialisten echter steeds nauwkeuriger een diagnose stellen.

Een reden kan zijn geweest, dat de specialisten een wollediger beeld van de patiënt verkregen, doordat ze ten behoeve van de computer een vragenlijst met relevante kenmerken, verkregen uit anamnese en lichamelijk onderzoek, moesten invullen. Pas nadat de artsen hadden beslist, wat er met de patiënten ging gebeuren, werden zij geconfronteerd met de uitkomsten van de regel van Bayes. Deze continue feedback kan eveneens de kwaliteit van de uitspraken van de arts hebben verhoogd. Wat de verklaring ook geweest moge zijn, van een leereffekt was nauwelijks sprake: nadat de computer de afdeling had verlaten, nam de $k$ waliteit van de uitspraken weer af.

\section{MEDISCHE BESLISKUNDE}

Ook in de medische besliskunde wordt de regel van Bayes toegepast. Wat medische besliskunde inhoudt zullen we in het nu volgende deel van mijn betoog duidelijk maken. Ten behoeve van een rationele aanpak van een bepaald probleem bij een patiënt schetst een arts voor zichzelf al zijn mogelijke handelwijzen, hoe een patiënt daarop kan reageren, zijn reaktie dáár weer op, enz. Bij een patiënt, verdacht van appendicitis, kan de arts zich bijvoorbeeld de volgende drie mogelijke handelwijzen voorstellen: de patiënt direkt opereren, de patiënt na zes uur opnieuw evalueren of de patiënt naar huis te sturen. In het geval hij beslist voor opereren is er een geringe kans dat de patiënt overlijdt. De hoogte van de kans hangt af van de werkelijke toestand van de appendix. Bij een normale appendix is de sterftekans het geringst, bij een geperforeerde appendix het hoogst. De arts heeft geen volledige zekerheid, dat de patiënt inderdaad appendicitis heeft. Een patiënt kan dus ten onrechte worden geopereerd en daardoor aan een onnodig risico worden blootgesteld. Daarom kan wachten een oplossing bieden, omdat men na zes uur meer zekerheid heeft. Ook dan moet de arts beslissen: bijvoorbeeld door de patiënt naar huis te sturen als de klachten verminderd zijn, door te opereren wanneer de klachten verergerd zijn of door opnieuw te kiezen tussen opereren en naar huis sturen bij gelijkblijvende klachten. Wanneer besloten wordt zes uur te wachten, terwijl de patiënt appendicitis heeft, zal zijn toestand mogelijk zijn verslechterd en de kans op een geperforeerde appendix zijn toegenomen met daardoor een toegenomen sterftekans. Aan de andere kant is de sterftekans bij een ontstoken of geperforeerde appendix, wanneer de patiënt naar huis wordt gestuurd, zeer groot. Dit is het moeilijke parket, waarin de arts zich bevindt. Om rationeel te kunnen beslissen, kan de arts nu alle mogelijkheden op een rijtje zetten met behulp van een beslissingsboom. 
Daarbij moet hij er achter zien te komen, wat de kans op een normale, een ontstoken of geperforeerde appendix is in geval van verdenking op appendicitis en hoe dexe kansen veranderen na zes uur wachten. Betrouwbare getallen zijn niet altijd gemakkelijk te verkrijgen, ook niet uit de literatuur. Beschikt men wel over deze getallen, dan kan via terugrekenen worden bepaald welke strategie het minste sterfterisico voor de patiënt oplevert.

In het hier besproken voorbeeld werd de sterftekans als kriterium gebruikt voor de keuze van de optimale therapie. In vrij veel situaties zijn de mogelijke uitkomsten niet vergelijkbaar en dienen de uitkomsten derhalve eerst onder één noemer te worden gebracht. Om rationeel te kunnen beslissen, zullen we in zo'n geval alle uitkomsten van een waarde-oordeel moeten voorzien. Dat dergelijke waarde-oordelen moeilijk te geven zijn wordt duidelijk, wanneer men bijvoorbeeld het verschil tussen genezen, amputatie onder de knie, amputatie boven de knie en overlijden moet kwantificeren, zoals dat wordt vereist in een ander bekend besliskundig voorbeeld van een diabetes patient met gangreen aan het onderbeen als gevolg van vasculaire insufficiëntie.

Als de utiliteiten eenmaal geschat zijn, $k$ an men met behulp van de regel van Bayes terugrekenen, wat elke beslissing aan het begin van de boom waard is. Als dan bij het appendicitis probleem de kosten van de beslissing 'direkt opereren' lager uitvallen dan die van de alternatieven 'zes uur wachten' of 'de patiënt naar huis sturen', zal de arts altijd direkt opereren. Statistisch gesproken neemt hij dan de beste beslissing.

Het zal evenwel uit het voorgaande duidelijk zijn, dat de beslissing gebaseerd is op kansen, die veelal niet goed bekend zijn en op utiliteiten, waarvan de waarde ook discutabe】kan zijn. Om meer zekerheid over de juistheid van een bepaalde beslissing te verkrijgen kan de arts kansen of utiliteiten wijzigen en waarnemen welke gevolgen dit heeft voor de uiteindelijke beslissing. Verandert deze niet, dan kan de arts meer vertrouwen hebben in het resultaat van zijn besliskundige exercitie.

\section{DISCRIMINANTANALYSE EN CLUSTERANALYSE}

Andere veel gebruikte statistische klassifikatiemethoden zijn de discriminantanalyse en de clusteranalyse. Bij de klassifikatie van slaap EEG's is het probleem bijvoorbeeld het volgende. Het tijdens de slaap opgenomen EEG wordt door neurologen beoordeeld. Daartoe worden segmenten EEG van dertig seconden geklassiliceerd in een aantal slaapstadia. Aangezien slaap EEG's langdurige opnamen zijn, is de neuroloog geruime tijd bezig dergelijke EEG's te klassificeren. Automatisering van dit gebeuren heeft derhalve nut. Ten behoeve van de klassifikatie moeten die kenmerken worden bepaald, die de afzonderlijke segmenten van het EEG karakteriseren. Uit onderzoek blijkt, dat het EEG signaal beschreven kan worden door een zestal kenmerken, die uiteraard als funktie van de tijd varieren. Uitgaande van de aanname, dat een EEG signaal gedurende de periode van een seconde als stationair kan worden beschouwd, kunnen de parameterwaarden over één seconde gemiddeld worden, waardoor elk EEG interval van een seconde 
beschreven kan worden door de waarden van slechts zes parameters. Mathematisch kan dit EEGinterval dan voorgesteld worden als een punt in een zes dimensionale ruimte. Als deze procedure wordt uitgevoerd voor alle tot een slaap EEG behorende intervallen, kan worden vastgesteld, dat er in de zes dimensionale ruimte clusters - dat zijn verdichtingen van punten - ontstaan. Als er evenveel clusters zijn als slaapstadia in het EEG, wordt de klassifikatie met behulp van de discriminantanalyse voor de hand liggend. Met behulp van de discriminantanalyse slaat men als het ware een aantal wanden om de clusters heen, zodat elke cluster in een afzonderlijke ruimte terecht komt. Elke ruimte vertegenwoordigt dan een slaapstadium. Heeft men een nieuw EEG interval dan behoeft men slechts na te gaan in welke ruimte het punt, dat met dit interval overeenkomt, terechtkomt om het juiste stadium te vinden. In de praktijk blijken er echter meer clusters te ontstaan dan er slaapstadia zijn, zodat discriminantanalyse geen oplossing biedt.

Daarom geven we alle punten, die tot een bepaald cluster behoren, eerst een etiket, dat verder willekeurig kan zijn, maar karakteristiek is voor alle punten, die tot het cluster behoren. Op deze manier kumnen alle intervallen van het slaap EEG van een etiket worden voorzien. Op basis van de besproken clusteranalyse kan nu elk segment van dertig seconden worden weergegeven door een profiel, dat aangeeft hoe vaak welke etiketten in zo'n segment voorkomen.

Door in een leerfase de gemiddelde profielen van de verschillende slaapstadia te berekenen, wordt het mogelijk nieuwe segmenten te klassificeren door te bepalen, op welk profiel van de verschillende slaapstadia het profiel van het beschouwde segment het meest lijkt. De procedure blijkt even nauwkeurig te zijn als de neuroloog, wanneer men de waarnemer variabiliteit tussen neurologen in aanmerking neemt.

We hebben een aantal klassifikatietechnieken ten tonele gevoerd, die het diagnostisch proces kunnen ondersteunen. De vraag kan natuurlijk gesteld worden, hoe men de optimale methode bepaalt voor een gegeven klassifikatieprobleem. Onderzoek heeft uitgewezen, dat de verschillende methoden toegepast op hetzelfde bestand, vergelijkbare resultaten opleveren. De grote verschillen in klassifikatieresultaten worden bepaald door het probleem en dus in feite door de discriminerende eigenschappen van de kenmerken, die men voor de klassillikatie ter beschikking heeft.

\section{SYMBOLISCH REDENEREN}

De hierboven besproken methoden zijn, afgezien van de logische methode, statistisch van aard en de klassifikatiekriteria, die uit deze aanpak volgen, blijken voor de arts soms moeilijk te interpreteren. Het komt er in zulke gevallen op neer, dat de arts de uitkomsten van de computer slaafs moet overnemen. Daarom zijn er onderzoekers, die trachten het denken van de arts in hun programma's te simuleren, zodat deze de uitkomsten van een analyse beter kan beoordelen. Consultatieve systemen, ook wel expert systemen genoemd, zijn een voorbeeld 
van een dergelijk streven. Hoewel oorspronkelijk bedoeld om het menselijk denken te modelleren, gaat het bij consultatieve systemen naar mijn mening veel meer om een nieuwe techniek van programmeren, waarbij de kennis van een bepaald gebied onafhankelijk wan de programmatuur wordt opgeslagen.

Consultatieve systemen bestaan uit een aantal onderdelen. Een daarvan is het kennisbestand. Het programma, dat met deze kennis kan redeneren wordt het inferentiemechanisme genoemd. Dit redeneermechanisme is meestal vrij eenvoudig. Het is namelijk de kennis, die een consultatief systeem waardevol maakt en niet zozeer de ingewikkeldheid van het redeneermechanisme.

Naast het kennisbestand is er een bestand aanwezig, waarin de gegevens van een specifieke patiënt worden opgeslagen.

Consultatieve systemen kunmen artsen ondersteunen in hun werk. Daarbij valt te denken aan systemen, die de arts bepaalde behandelingen suggereren of aan systemen, die het handelen van de arts bewaken en die pas bij verkeerde beslissingen de arts hierop attenderen.

De kennis, die in het kennisbestand is opgeslagen, is afkomstig van materiedeskundigen. Deze kennis kan door de materiedeskundigen zelf in het systeem zijn ingevoerd, terwijl het ook mogelijk is dat de kennisacquisitie via een intermediair, de zogenaamde kennisanalist, heeft plaatsgevonden.

De kennis dient uiteraard up-to-date te worden gehouden. Wie zich hiervoor ook garant stelt, uiteindelijk zal de arts, die een dergelijk systeem gebruikt, verantwoordelijk zijn voor het feit of hij al dan niet de suggestie van het consultatief systeem overneemt. Wil de arts een voorstel voor zijn rekening kunnen nemen, dan zall het systeem in staat moeten zijn de redenen aan te geven op basis warvan het desbetreffende voorstel werd gedaan. Een consultatief systeem beschikt daarom ook over een uitlegfaciliteit.

Een consultatief systeem kan niet alles beredeneren. Het heeft, om tot een advies te komen, specifieke patiëntgegevens nodig. Deze gegevens worden door de gebruiker aangeleverd en daarna opgeslagen in een apart bestand. Hoewel de communicatie tussen systeem en gebruiker menselijk en intelligent overkomt, loopt het programma zeer dom alle mogelijkheden af. In feite is een consultatief systeem, zoals hier in het kort beschreven, niets anders dan een uitgebreide beslissingsboom.

\section{BETEKENIS VAN DE MEDISCHE INFORMATICA VOOR DE ARTS}

In het voorgaande heb ik $U$ in vogelvlucht een aantal toepassingen uit de medische informatica voorgeschoteld. Daarbij heb ik mij steeds geconcentreerd op het toepassingsgebied. Bij de gekozen voorbeelden was het tot op zekere hoogte mogelijk de oplossing van het probleem te formaliseren. Een aantal van de U voorgelegde problemen waren van dusdanige omvang, dat het zonder computerondersteuning niet mogelijk zou zijn geweest ze op te lossen, denkt U bijvoorbeeld maar aan de computertomografie. Overigens is de beschik baarheid van een computer slechts een van de vereisten voor de oplossing van een probleem. Ook het methodologisch inzicht is van belang. Bij besluitvormingsondersteunende syste- 
men bijwoorbeeld kan men vaak niet terugvallen op kennis omtrent de wijze, waarop mensen beslissingen nemen. Hoe de denkprocessen verlopen is onderwerp van studie, maar de resultaten zijn niet dusdanig, dat vaak modellen van denkprocessen operationeel gemaakt kunnen worden in een computersysteem. Voor de oplossing van een diagnostisch probleem zal de informaticus derhalve gebruik maken van pathofysiologische kennis verband houdend met het probleem en zal hij gewapend met een grote dosis gezond verstand de verschillende hem bekende methoden op geschiktheid testen. De arts zal op zijn beurt die kenmerken opsommen, die naar zijn mening bij de klassifikatie een rol spelen.

Met behulp van een leerbestand - een goed gedocumenteerd bestand van patiëntgegevens - worden dan de klassifikatieregels bepaald, die met behulp van een onafhankelijk testbestand - eveneens een goed gedocumenteerd bestand op hun geschiktheid worden beoordeeld.

Computer ondersteunde diagnostiek wordt in de praktijk nog weinig toegepast. De analyse van ECG's vormt hierop, in ieder geval in het buitenland, een uitzondering. Een reden voor dit geringe gebruik kan zijn, dat de desbetreffende programma's een dusdanig beperkt bereik hebben, dat ze voor de arts nauwelijks de moeite waard zijn. Het onderwerp kan gekozen zijn omdat het geschikt was voor het uittesten van een methode zonder dat de relevantie voor de arts werd nagegaan.

Een andere reden zou kunnen zijn, dat de arts bang is, dat deze systemen hem op den duur zullen vervangen. Als de resultaten van diagnostische programma's beter zijn dan de resultaten van de arts - zoals dat op verschillende gebieden inderdaad het geval is - waarom dan niet goedkopere apparatuur in plaats van artsen ingezet? Bovendien: computers raken niet vermoeid, zijn consistent, snel, nauwkeurig en hebben een groot geheugen.

Dat een arts door de computer niet vervangen kan of mag worden vanwege de aard van de computeruitspraken, hoop ik meteen duidelijk te maken. Wat het geringe gebruik van computer ondersteunde diagnostiek betreft, wil ik nog opmerken, dat door middel van gericht onderwijs de behoefte aan computerondersteuning zal toenemen. Daarbij dienen we ons echter steeds te bedenken dat niet alles, wat geprogrammeerd kán worden ook gemaakt móet worden. Computerprogramma's dienen daar te worden ingezet, waar ze de arts inderdaad ondersteunen en waar ze tot betere resultaten voor de patiënt aanleiding geven. Om vast te stellen, waarom een computer de arts niet kan of mag vervangen moeten we ons bedenken, dat de kennis, die in programma's wordt gebruikt, wetenschappelijk van aard is. Deze kennis is verkregen via wetenschappelijk onderzoek, dat zich kenmerkt door analyse en abstractie. Wat bedoelen we daarmee? In de wetenschap bestuderen we bepaalde aspecten van de werkelijk heid en niet de gehele werkelijkheid. Zo bestudeert de biologie bijvoorbeeld de biotische en de economie de economische aspekten van de werkelijkheid. Beide vakgebieden bestuderen dezelfde werkelijkheid, maar vanuit verschillende invalshoeken.

$\mathrm{Er}$ is nog een andere vorm van abstractie. Binnen alle vakgebieden abstraheert men van het individuele. Het gaat er in de wetenschap om universeel geldende wetten op te stellen. Deze reduktie van de werkelijkheid vindt ook plaats wanneer 
ziekteprocessen worden bestudeerd. Hoewel elke patiënt unjek is, ook al behoort hij met andere patiënten tot een zelfde ziektecategorie, voor de wetenschap zijn deze patiënten gelijk. De geneeskunde als wetenschap doet uitspraken over DE patient, niet over een individuele patiënt. Artsen daarentegen hebben te maken met individuele patiënten. Bovendien hebben zij als mens de zorg voor lijdende medemensen. Als mens weet de arts wat pijn betekent, wat angst is, enz.

In zijn besluitvorming zal de arts terdege rekening dienen te houden met de wetenschappelijke uitspraken, zoals deze bijwoorbeeld via een daartoe geschikt computerprogramma zijn verkregen. Zijn beslissing houdt echter meer in dan datgene, waartoe de conclusies van een programma kunnen leiden. De arts beslist - in samenspraak of rekening houdend met de patiënt - over diens toekomst. Over de toekomst van een individuele patiënt zijn geen wetenschappelijke uitspraken te doen. Voor de mens bergt de toekomst onzekerheden. Wetenschappelijke uitspraken kennen een dergelijke onzekerheid niet. Als wordt voorspeld, dat dertig procent van de patiënten niet op een bepaalde therapie zal reageren, zal dit bij een goed model ook uitkomen. Maar het model doet geen uitspraak over het feit, welke patiënt positief zal reageren en wellke niet, ook al kunnen er faktoren een rol spelen, die de kans op een positieve reaktie van een bepaalde patiënt op de therapie vergroten. Een computermodel kent geen toekomst in de zin van mogelijk verrassende wendingen. De toekomst is bij een computermodel gedletermineerd.

Het zal duidelijk zijn, dat de arts niet door een computer kan worden vervangen, indien men de individuele patiënt recht wil doen en wanneer men de verantwoordelijkheid wil laten daar waar hij hoort, namelijk bij de arts.

Ook al blijkt de computer consistenter en betrouwbaarder dan de arts, de conclusie wan het programma betreft slechts een onderdeel van de totale beslissing, waaruit het individuele is verdwenen. Het is aan de arts deze wetenschappelijke conclusies te individualiseren, rekening houdend met de toekomstverwachtingen van de patiënt, de omgeving waarin hij verkeert, zijn psychisch inkasseringsvermogen, enz.

Toepassing van de medische informatica leidt - ondanks het gebruik van computers - niet tot dwingende beslissingen en in ieder geval niet tot een zekere toekomst voor arts en patiènt. Wel biedt de toepassing ondersteuning, waardoor arts en patiënt in vrijheid, mede op grond van de door het programma geleverde gegevens, de voor deze specifieke patiënt meest geschikte behandeling kunnen kiezen. 
Dames en heren,

Alvorens af te sluiten wil ik mijn dank betuigen aan allen, met wie ik in de afgelopen jaren heb samengewerkt.

Hooggeleerde van Loef,

Wetenschappelijk ben ik voor een niet gering deel gevormd binnen de vakgroep Stralingsfysica van de TH in Delft. Aan mijn afstudeerperiode en aan de drie jaar, die ik bij $U$ aan mijn promotie heb gewerkt, denk ik nog steeds met veel voldoening terug. Ik wil $U$ en in $U$ al mijn collegae van destijds nogmaals hartelijk danken voor de wijze waarop zij aan mijn wetenschappelijke vorming hebben bijgedragen.

Hooggeleerde Penn,

In de drie jaar, die ik bij professor Kazem op de afdeling Radiotherapie en Nucleaire Geneeskunde heb gewerkt, hebben wij veel kontakten gehad, onder andere resulterend in een aantal publikaties en de organisatie van het CARD congres. $\mathrm{U}$ en professor Kazem, die helaas door zijn vertrek naar de Verenigde Staten hier niet aanwezig kan zijn, hebben mij ingewijd in de voor mij belangrijke aspekten van de geneeskunde. In mijn dank wil ik Jan de Jong niet vergeten, die gedurende de drie jaar, die ik in Nijmegen verbleef, voor mij een zeer gewaardeerde collega, ja zelfs bijna een vader was.

Hooggeleerde van Bemmel,

De langste tijd was ik verbonden aan de vakgroep Medische Informatica van de VU. Toen je mij in 1974 op een gegeven ogenblik voor het blok zette - ik moest binnen een uur nu maar eens beslissen of ik in Nijmegen zou blijven dan wel de uitdaging van een nieuw vakgebied wilde aangrijpen - heb ik, achteraf bezien, de op twee na beste keuze van mijn leven gemaakt. Deze beslissing wordt alleen nog overtroffen door de keuze van mijn ouders en de keuze van mijn vrouw en kinderen beslissingen die ik overigens niet helemaal zelfstandig heb kunnen nemen!

Beste Jan, veel - ja waarschijnlijk wel alles van wat ik hier naar voren heb gebracht - zal je bekend in de oren hebben geklonken. Gedurende de elf jaren, die ik in Amsterdam verbleef, heb ik veel van je geleerd. Ik heb - naast je vakinhoudelijke kijk op zaken altijd veel genoegen gesmaakt van je meer filosofisch getinte benadering wan ons wak. Dat ik daar een tik van meegekregen heb zal uit mijn voordracht duidelijk zijn geworden.

Alle collega's van de vakgroep Medische Informatica wil ik bedanken voor de prettige samenwerking van jaren. Ik zal deze tijd niet licht vergeten.

Geachte dames en heren, leden van de wetenschappelijke en niet wetenschappelijke staf,

De matrix-organisatie, die ik binnen de RL aantrof, is voor onze capaciteitsgroep ideaal om kennis en kunde op het gebied van de medische informatica binnen projekten in te brengen. Ik ben ervan overtuigd, dat er een vruchtbare samenwerking met velen van $U$ zal ontstaan. 
Dames en heren studenten,

Ik hoop dat uit mijn betoog duidelijk is geworden welke rol de medische informatica in de gezondheidszorg speelt. Graag willen wij $U$ inwijden in de geheimen van dit vakgebied. Daarbij bent U op twee manieren welkom: als student, die onderwijs ontyangt en als student, die feedback levert over het gegeven onderwijs en meehelpt aan de verdere uitbouw ervan. Ik stel me er veel van voor.

Tot slot wil ik $U$ allen, zeer gewaardeerde toehoorders, danken voor $U w$ belangstelling. $1 \mathrm{k}$ heb gezegd. 